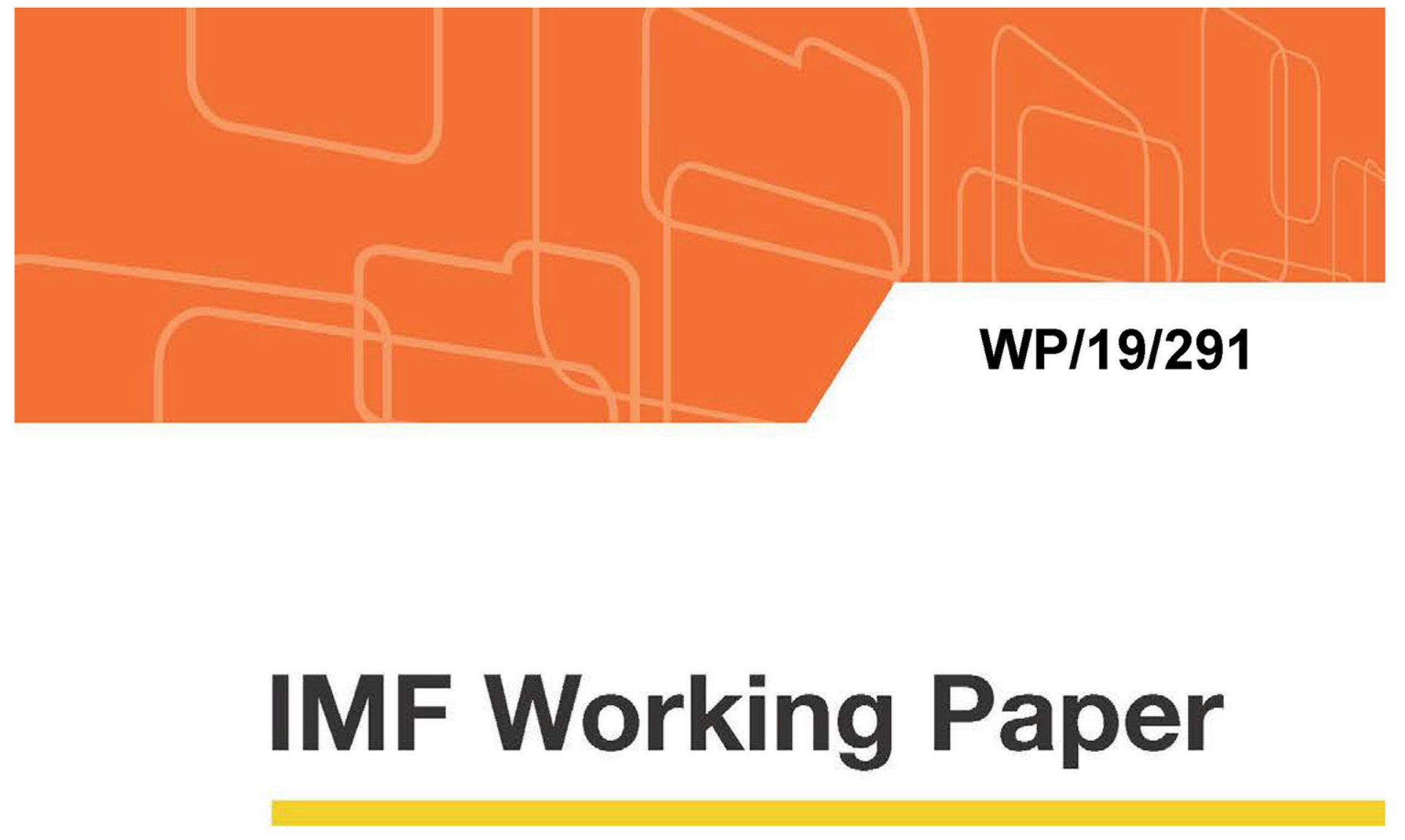

\title{
Do Fiscal Rules Cause Fiscal Discipline over the Electoral Cycle?
}

by Kodjovi M. Eklou

Marcelin Joanis

IMF Working Papers describe research in progress by the author(s) and are published to elicit comments and to encourage debate. The views expressed in IMF Working Papers are those of the author(s) and do not necessarily represent the views of the IMF, its Executive Board, or IMF management. 


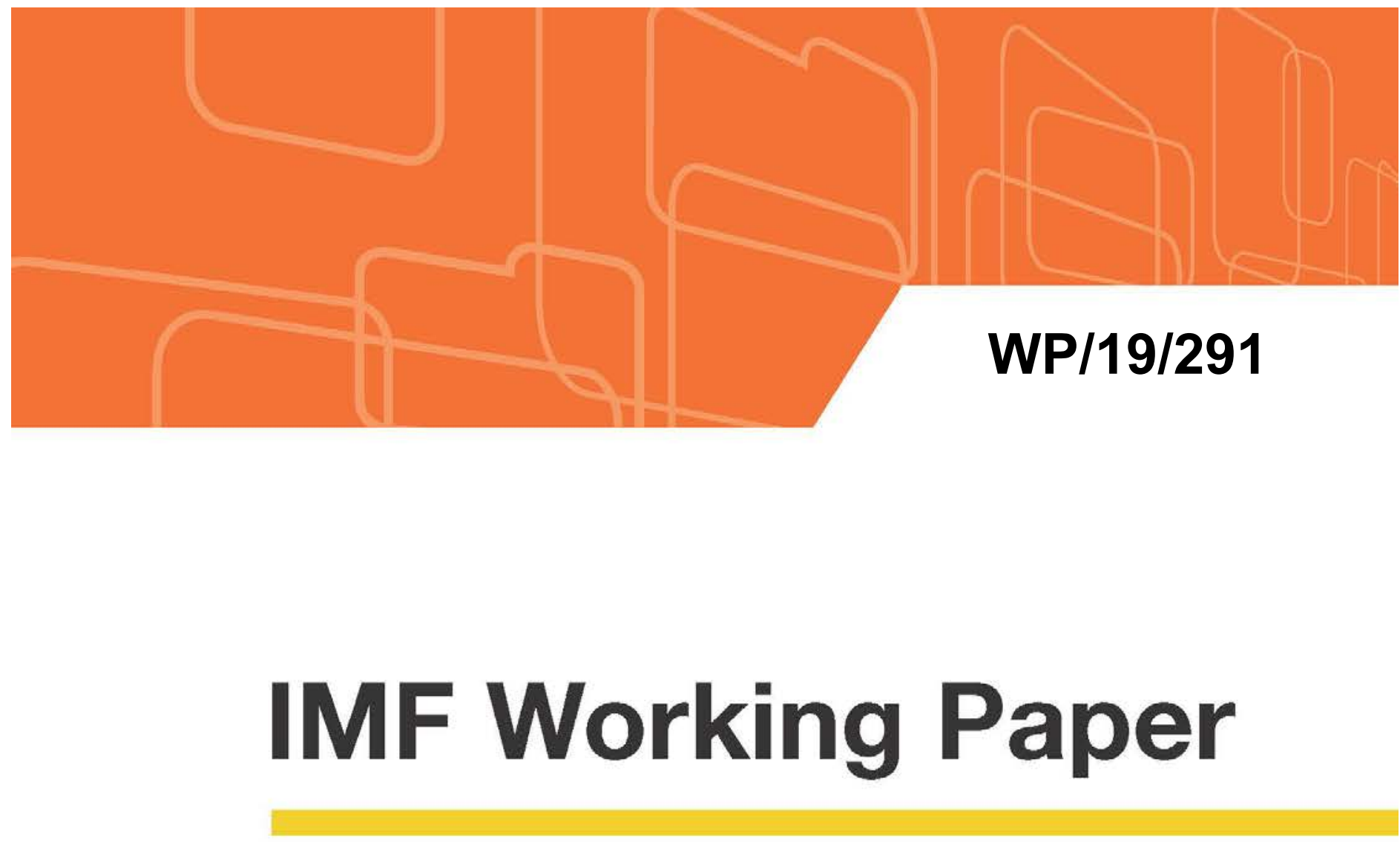

\section{Do Fiscal Rules Cause Fiscal Discipline over the Electoral Cycle?}

by Kodjovi M. Eklou

Marcelin Joanis

IMF Working Papers describe research in progress by the author(s) and are published to elicit comments and to encourage debate. The views expressed in IMF Working Papers are those of the author(s) and do not necessarily represent the views of the IMF, its Executive Board, or IMF management. 


\title{
IMF Working Paper
}

\author{
European Department
}

\author{
Do Fiscal Rules Cause Fiscal Discipline Over the Electoral Cycle?* \\ Prepared by Kodjovi M. Eklou, and Marcelin Joanis \\ Authorized for distribution by Rachel van Elkan
}

December 2019

\begin{abstract}
IMF Working Papers describe research in progress by the author(s) and are published to elicit comments and to encourage debate. The views expressed in IMF Working Papers are those of the author(s) and do not necessarily represent the views of the IMF, its Executive Board, or IMF management.
\end{abstract}

\begin{abstract}
This paper estimates the causal effect of fiscal rules on political budget cycles in a sample of 67 developing countries over the period 1985-2007. We exploit the geographical pattern in the adoption of fiscal rules to isolate an exogenous source of variation in the adoption of national fiscal rules. Based on a diffusion argument, we use the number of other countries in a given subregion that have fiscal rules in place to predict the probability of having them at the country level. We find that in election years with fiscal rules in place, public consumption is reduced by 1.6 percentage point of GDP as compared to election years without these rules. This impact is equivalent to a reduction by a third of the volatility of public consumption in our sample.

Furthermore, the effectiveness of these rules depends on their type, their institutional design, whether they have been in place for a long time and finally on the degree of competitiveness of elections.
\end{abstract}

JEL Classification Numbers: D72; E62; H5; O11.

Keywords: Fiscal Rules; Fiscal Discipline; Election; Political Budget Cycles; Developing Countries.

Author’s E-Mail Address: KEklou@imf.org; Marcelin.joanis@polymtl.ca

\footnotetext{
${ }^{*}$ We thank Etienne Farvaque, Martino Pelli, Antonio Afonso, seminar/conference participants at NIPFP (New Delhi), Universite' de Lille, IIPF (Tokyo), CEA (Montr'eal) and SCSE (Ottawa) for their comments. The views expressed in this paper do not necessarily represent the views of the IMF, its Executive Board, or IMF management.
} 


\title{
Do fiscal rules cause fiscal discipline over the electoral cycle? Evidence from developing countries*
}

\author{
Kodjovi M. Eklou ${ }^{\mathrm{a}}$, Marcelin Joanis ${ }^{\mathrm{b}}$ \\ a International Monetary Fund, E-mail: KEklou@imf.org \\ ${ }^{\text {b} P o l y t e c h n i q u e ~ M o n t r e ́ a l ~ a n d ~ C I R A N O . ~ C . P . ~ 6079, ~ s u c c . ~ C e n t r e-v i l l e, ~ M o n t r e ́ a l, ~ H 3 C ~ 3 A 7, ~ Q u e ́ b e c-C a n a d a, ~ E-m a i l: ~}$ \\ marcelin.joanis@polymtl.ca ; Phone: +1 (514) 340-4711 poste 3356.
}

September, 2019

\begin{abstract}
This paper estimates the causal effect of fiscal rules on political budget cycles in a sample of 67 developing countries over the period 1985-2007. We exploit the geographical pattern in the adoption of fiscal rules to isolate an exogenous source of variation in the adoption of national fiscal rules. Based on a diffusion argument, we use the number of other countries in a given subregion that have fiscal rules in place to predict the probability of having them at the country level. We find that in election years with fiscal rules in place, public consumption is reduced by $1.65 \%$ point of GDP as compared to election years without these rules. This impact is equivalent to a reduction by a third of the volatility of public consumption in our sample. Furthermore, the effectiveness of these rules depends on their type, their institutional design, whether they have been in place for a long time and finally on the degree of competitiveness of elections.
\end{abstract}

Keywords: fiscal rules, fiscal discipline, election, political budget cycles, developing countries.

JEL Classification: D72; E62; H5; O11.

${ }^{*}$ We thank Etienne Farvaque, Martino Pelli, Antonio Afonso, seminar/conference participants at NIPFP (New Delhi), Université de Lille, IIPF (Tokyo), CEA (Montréal) and SCSE (Ottawa) for their comments. The views expressed in this paper do not necessarily represent the views of the IMF, its Executive Board, or IMF management. 


\section{Contents}

$\begin{array}{lr}\text { Introduction } & \underline{\mathbf{3}}\end{array}$

1 Data and empirical methodology $\underline{6}$

1.1 Empirical strategy $\ldots \ldots \ldots \ldots \ldots$

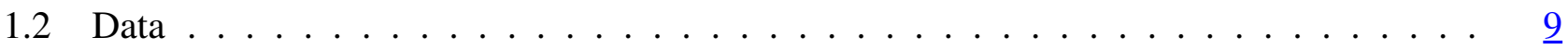

2 Results $\quad \underline{12}$

2.1 Determinants of fiscal rule adoption . . . . . . . . . . . . . . $\underline{12}$

2.2 The design of fiscal rules, the experience with rules and the cycle . . . . . . . . . $\underline{15}$

3 Robustness: testing for overidentifying restrictions $\quad \underline{17}$

$\begin{array}{lr}\text { Conclusion } & \underline{18}\end{array}$

$\begin{array}{ll}\text { Appendix } & \underline{32}\end{array}$

\section{List of Tables}

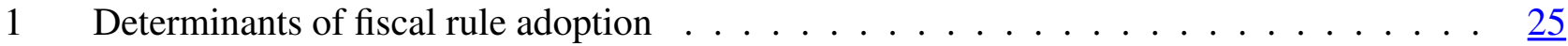

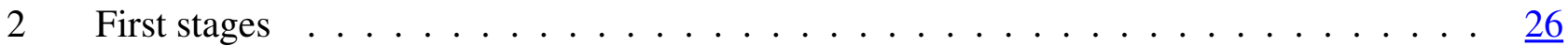

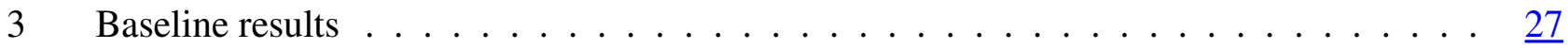

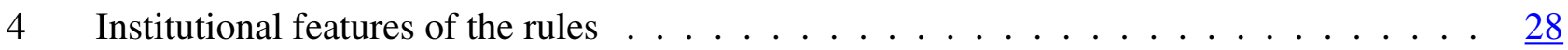

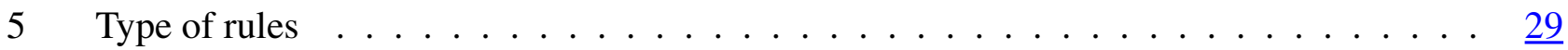

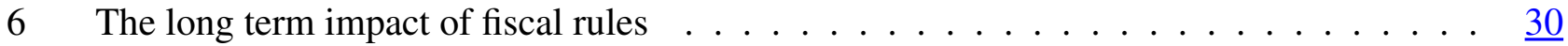

7 Testing for overidentifying restrictions $\ldots \ldots \ldots \ldots \ldots \ldots$ 


\section{Introduction}

In order to increase their chances of reelection, politicians are known to undertake fiscal manipulations, especially in election years (Rogoff, 1990). These fiscal manipulations typically take the form of increased public expenditures, and will often lead to fiscal indiscipline and macroeconomic volatility. Therefore, an important policy issue is how to curb such politically motivated public spending. Many countries, both developed and developing, have adopted fiscal rules in recent decades as an attempt to enforce fiscal discipline.

The idea that fiscal rules might tame the political budget cycle has garnered theoretical support. In an extension of Rogoff and Sibert (1998)'s theoretical framework, Rose (2006) shows that a binding (balanced budget) rule eliminates the political budget cycle. It does so by preventing an incumbent from running a deficit and thus rendering all elements of fiscal policy (public spending and tax) contemporaneously visible to the voter. Voters can infer the competence of the incumbent, who no longer derives an electoral advantage from fiscal policy manipulation as a signaling tool. A growing empirical literature has demonstrated the effectiveness of these institutional constraints on fiscal policy in various developed country contexts (Rose, 2006; Krogstrup and Wälti, 2008; Grembi et al., 2016). Yet, the findings in developed countries may not be a good benchmark for developing countries because of the potential weakness in the enforcement capacity of the latter.

In this paper, we employ a cross-country panel dataset in order to test whether fiscal rules adopted in developing countries have been effective in constraining political budget cycles. The dataset covers 67 developing countries over the period 1985-2007 in order to focus on fiscal rules adopted prior to the financial crisis and the fiscal distress that followed. Our dependent variable is the general government's final consumption expenditure as a share of GDP. A good proxy for discretionary fiscal policy (Fatás and Mihov, 2003). In developing countries, the main instrument of expansionary fiscal policies around elections has indeed been shown to be increasing public expenditures (Schuknecht, 2000; Block, 2002).

The empirical strategy relies on an original two-step instrumental variable approach to investigate the 
causal effect of fiscal rules, as the endogeneity of fiscal rules is a serious issue that cannot be avoided. The identification of the causal effect of fiscal rules is challenging for two main reasons: a reverse causality problem (the fiscal stance can determine the adoption of fiscal rules) and an omitted variable bias (voter preference for fiscal discipline can determine both the adoption of fiscal rules and budgetary outcomes). In this paper, we address both issues. To address the potential of reverse causality, we exploit the geographical distribution of countries that have fiscal rules in place to instrument for national fiscal rules. As geographical proximity is known to be a powerful channel of diffusion of policy reforms (Brueckner, 2003; Pitlik, 2007), the probability that a country has fiscal rules in place is likely to increase with the number of neighboring countries that have implemented similar policies. We thus use the number of neighboring countries that have fiscal rules in a given subregion to predict the probability of adopting national fiscal rules. We then use the predicted probability as an instrument. We argue that the geographical pattern in the adoption of fiscal rules offers a unique source of causal inference. The subregional popularity of fiscal rules should affect fiscal policy decisions at a country level only through this country's choice of having fiscal rules. Caselli and Reynaud (2019) use a similar identification strategy where they instrument domestic fiscal rules with the number of countries with common borders having fiscal rules. ${ }^{1}$ We provide several arguments supporting the validity of the exclusion restriction. Furthermore, to address the second endogeneity issue (omitted variable bias), we exploit the panel structure of the dataset to account for unobserved preferences by including country fixed effects and country-specific linear trends in all specifications.

Our empirical evidence in a sample of 67 developing countries over the period 1985-2007, shows that fiscal rules cause fiscal discipline over the electoral cycle. ${ }^{2}$ More specifically, in election years with fiscal rules in place, public consumption is reduced by $1.65 \%$ point of GDP as compared to election years without these rules. Furthermore, the effectiveness of these rules depends on their type, their insti-

\footnotetext{
${ }^{1}$ While our approach is similar to Caselli and Reynaud (2019), this identification strategy was previously developed in chapter 2 of Eklou (2018). Further, Caselli and Reynaud (2019) estimate the impact of fiscal rules on fiscal balance in a sample of 142 countries while our focus is on discretionary fiscal policy in the context of developing countries over the electoral cycle.

${ }^{2}$ While poorly designed rules can limit the ability to use discretionary fiscal policy during downturns, the issue of a tradeoff between flexibility and stringency is beyond the scope of this paper. Our focus is on the effectivenesss of fiscal rules in curbing politically motivated public spending.
} 
tutional design and whether they have been in place for a long time. In particular, expenditure rules, rules covering the general government and rules characterized by a monitoring body outside the government dampen political budget cycles in government consumption. These results are novel in showing that both the level of government targeted by the rules and the monitoring of the compliance with these rules do matter for the political budget cycle. Also, following the literature, we explore the effect in democracies and find that this discipline effect is particularly strong during competitive elections.

This paper is closely related to a relatively limited literature on the effect of fiscal rules on political budget cycles. Rose (2006) finds that in American states, stringent balanced budget rules limit the ability of the incumbents to manipulate fiscal policy for electoral purpose. Most recent studies take into account one of the endogeneity issues mentioned above, i.e. the omitted variable bias. For instance, Krogstrup and Wälti (2008) control for fiscal preferences in the case of Swiss sub-federal jurisdictions. Grembi et al. (2016) use a quasi-experimental design to estimate the impact of fiscal rules in Italian municipalities, exploiting the imposition of fiscal rules on municipal governments in 1999 that was later relaxed for municipalities below 5000 inhabitants.

While that literature is mostly focused on developed countries, we are aware of a couple of exceptions. ${ }^{3}$ Ebeke and Ölçer (2013) investigate the effect of fiscal rules on the political budget cycle in low income countries. However, as they acknowledge, their analysis is focused on a sample of low income countries with only 4 countries that have fiscal rules in place raising concerns about the reliabilty of the statistical inference. Our sample includes all developing countries (including low income countries) and we have a larger sample of countries with fiscal rules. In addition, Ebeke and Ölçer (2013) do not address the endogeneity of fiscal rules as we do in this paper. Another exception is Tapsoba (2012), who employs a matching approach (that is different from our instrumental variable strategies) to deal with the self selection problem in investigating the effects of fiscal rules on fiscal outcomes. The self selection problem can be viewed as an omitted variable bias problem that an intrumental variable strategy should address. This matching approach consists in pairing countries that have fiscal rules with countries that do not have them based on similar observables variables, and cannot unfortunately address the selection

\footnotetext{
${ }^{3}$ See for instance Bonfatti and Forni(2019).
} 
based on unobservables.

The paper is also related to a literature emphasizing the role of institutions in constraining the discretion of fiscal policy. For instance, Shi and Svensson (2006) show that the institutional environment may change politicians' incentives. Also, Fatás and Mihov (2006) find that fiscal rules reduce the discretionary use of fiscal policy (in the United States). In this vein, Schuknecht (2000) argues that intitutional mechanisms designed to constrain discretionary public spending may help prevent opportunistic policies around elections in developing countries. Finally, Kopits and Symansky (1998) stress that "the most powerful argument for fiscal rules centers on their political economy aspects."

The remainder of the paper is organized as follows. Section 1 presents the empirical methodology and the data employed to test the effect of fiscal rules on political budget cycles in developing countries, Section 2 reports the results and Section 3 uses an augmented empirical approach allowing us to test for overidentifying restrictions. Finally, we conclude.

\section{Data and empirical methodology}

\subsection{Empirical strategy}

Consider the following specification to test the effect of fiscal rules on political budget cycles:

$$
Y_{i t}=\beta_{1} \mathrm{elec}_{i t}+\beta_{2} \mathrm{elec}_{i t} \times F R_{i t}+\beta_{3} F R_{i t}+\beta_{4} X_{i t}+\alpha_{i}+\operatorname{trend}_{i}+\varepsilon_{i t}
$$

where $Y_{i t}$ is the general government consumption in percentage of GDP, $i$ and $t$ denote country and year respectively. elec is the election index developed by Franzese (2000) that captures the exact moment when an election is held and $F R$ is the fiscal rule dummy variable indicating if, in a specific year, there is a fiscal rule in place. $X$ is a set of control variables and $\alpha_{i}$ is a fixed effect that controls for any countryspecific constant characteristic. Finally, trend $_{i}$ is a country-specific trend and $\varepsilon_{i t}$ is an error term.

$\beta_{1}$ and $\beta_{2}$ are the main coefficients of interest. They capture, respectively, the effect of the political 
budget cycle and the effect of fiscal rules on the political budget cycle in public consumption. The hypothesis tested implies that $\beta_{1}>0$ and $\beta_{2}<0$, meaning that the presence of fiscal rules may dampen the pressure on public consumption in election years, following Rose (2006).

As outlined in the introduction, we address two main threats to the identification of the causal effect of fiscal rules in this paper. First, the adoption of fiscal rules may simply reflect voters' preferences for fiscal discipline (Poterba, 1996). Since these preferences may also have an influence on fiscal outcomes, it is important to control for them in order to be sure to identify a causal effect of fiscal rules. Including country-specific linear trends allows us to take into account all time-varying unobserved heterogeneity. The inclusion of the country-specific trend (together with the fixed effects) may then pick up voters' preferences for fiscal discipline which may vary over time and are potentially unobserved within country. ${ }^{4}$

The second potential source of bias in estimating the effect of fiscal rules on budgetary outcomes is the reverse causality issue (Ayuso-i-Casals et al., 2007; Kumar et al., 2009). Indeed, budgetary outcomes may themselves lead to the adoption of fiscal rules. In this regard, Schaechter et al. (2012) find that the fiscal distress that followed the financial crisis of 2008-2009 has led many countries to the adoption of fiscal rules. To address this second issue, we exploit the geographical pattern of the adoption of fiscal rules to instrument for the national fiscal rules at country level. We consider countries from three regions: Latin America, Subsaharan Africa and South Asia. The idea is based on an argument of regional diffusion of these rules. Specifically, the likelihood of a country adopting a fiscal rule should increase as the number of neighboring countries that have these rules in place becomes larger. Indeed geographical proximity is a powerful channel of the diffusion of policy reforms (Brueckner, 2003; Pitlik, 2007). Thus, for a given country, we use the number of neighboring countries in the region that have fiscal rules in place in a given year as an instrument.

To implement this IV strategy, we follow the approach developed by Wooldridge (2010) that allows to consistently estimate the effects of an endogenous dummy variable (that is fiscal rules in this case). In

\footnotetext{
${ }^{4}$ There is evidence that voters' preferences for fiscal discipline may evolve or change over time. See for instance Brender (2003) and Krogstrup and Wälti (2008).
} 
a first step, we estimate a Probit model where we regress $F R$ on the instrument and other covariates in order to predict a probability of having a fiscal rule in place as follows:

$$
\operatorname{Pr}\left(F R=1 \mid X_{i t}, \text { Neighbors }_{i t}\right)=\Phi\left(\delta_{0}+\delta_{1} \text { Neighbors }_{i t}+\delta_{2} X_{i t}\right)
$$

where $\Phi($.$) is the cumulative distribution function for a standardized normal random variable, Neighbors { }_{i t}$ (the instrument) is the number of neighboring countries in the region with a fiscal rule and $X$ a set of other covariates in the model. The mechanism that we suggest implies that $\delta_{1}>0$, meaning that the likelihood of having a fiscal rule in place in a given country increases with the number of neighboring countries with rules.

Having argued why the instrument should be correlated with fiscal rules' adoption, we turn now to the validity of the exclusion restriction. The identifying assumption is that the number of other countries in a subregion with fiscal rules in place (capturing the popularity of these rules) should have no effect on public consumption except through their effect on fiscal rules in a given country. This is reasonable since public spending in a country should not be affected by how popular a policy reform is in its subregion. One potential threat for the identification is that the number of other countries in the subregion may capture regional macroeconomic shocks that may affect fiscal policy. If these shocks are related to factors such as climate or geography (that are more likely) we may not worry about the violation of the exclusion restriction as they are exogenous. But if these factors are not exogenous, then our instrument may not meet the condition of exogeneity. In this regard, we control for economic growth, trade openness and public debt in our regressions. These variables capture the effects of potential subregional economic shocks. Moreover our specifications include country-specific linear trends that allow us to deal with time-varying omitted variables which may simultaneously affect the likelihood of fiscal rules' adoption and public consumption at country level. Therefore we find it unlikely that the exclusion restriction is violated. We also run regressions including sub-regional economic growth as well as global economic growth to control respectively for sub-regional common shocks and global macroeconomic trend. The results shown in Appendix E support our claim as our results appear to be robust to this specification. 
In a second step, we apply a standard IV estimator using the predicted probability $(\hat{F R})$ as an instrument for fiscal rules. As we have two endogenous variables (FR and the interaction term) in equation (1) we have two first stages. The first stage for fiscal rules is the following:

$$
F R=\theta_{1} \hat{F R}_{i t}+\theta_{2} \mathrm{elec}_{i t}+\theta_{3} \mathrm{elec}_{i t} \times \hat{F R} R_{i t}+\theta_{4} X_{i t}+\alpha_{i}+\operatorname{trend}_{i}+\eta_{i t}
$$

We instrument the interaction between election and fiscal rule by the interaction between election and $\hat{F R}$ as follows:

$$
\operatorname{elec}_{i t} \times F R_{i t}=\gamma_{1} \operatorname{elec}_{i t} \times \hat{F R}{ }_{i t}+\gamma_{2} \operatorname{elec}_{i t}+\gamma_{3} \hat{F R_{i t}}+\gamma_{4} X_{i t}+\alpha_{i}+\operatorname{trend}_{i}+\xi_{i t},
$$

noting that $\eta_{i t}$ and $\xi_{i t}$ are the error terms of the first stage equations.

This approach has several advantages. Firstly, it takes into account the binary nature of the endogenous fiscal rule dummy. Secondly, the usual IV standard errors are still asymptotically valid. Thirdly and most importantly, unlike the pseudo-IV approach (consisting in running an OLS estimate of $Y$ on $\hat{F R}$ ), this approach does not require the Probit model to be correctly specified (Wooldridge, 2010). We just need the instrument $\left(\right.$ Neighbors $_{i t}$ ) to be correlated with the probability of having a fiscal rule in place as specified in Equation (2). We employ the within IV estimator with clustered standard errors at country level which corrects the standard errors for arbitrary serial correlation.

\subsection{Data}

We employ a cross-country panel dataset in order to test the effect of fiscal rules on the political budget cycle in developing countries. The dataset covers 67 developing countries over the period 1985-2007. The sample selection is based on data availability and we focus on fiscal rules adopted before the financial crisis of 2008-2009. Focusing on the adoption of fiscal rules prior to the crisis should reduce the selection bias that may stem from the deterioration of the fiscal stance in many countries following this crisis. Indeed, many countries have adopted fiscal rules following the fiscal distress that characterized the financial crisis of 2008-2009 (Schaechter et al., 2012). The sample includes 13 countries with national 
fiscal rules over the period among which 11 have Balanced Budget Rules (BBR), 4 have Expenditure Rules (ER), 8 have Debt Rules (DR) and only one has a Revenue Rule (RR). ${ }^{5}$ Appendix B shows the descriptive statistics of the variables used in the empirical work.

Our main dependent variable of interest is the general government final consumption expenditure as a share of GDP (from World Development Indicator, WDI). Not only are public expenditures the most available fiscal variables, especially for a long period of analysis in developing countries, but they also represent a good proxy for discretionary fiscal policy (Fatás and Mihov, 2003). In addition, Schuknecht (2000) finds that, in developing countries, increasing public expenditures is the main instrument of expansionary fiscal policy around elections. Similarly, Block (2002) finds that fiscal expansions are pronounced in government consumption expenditure in a sample of African countries. Brender and Drazen (2005) also find that political budget cycles are driven by expenditure.

Data on fiscal rules are from the IMF Fiscal Rules Dataset, 2016, Schaechter et al.,(2012). They are coded as dummy variables indicating if, in a specific year, there is a fiscal rule in place. A fiscal rule is defined according to Kopits and Symansky (1998) as a "permanent constraint on fiscal policy expressed in terms of a summary indicator of fiscal performance". 6

Elections data are from the National Elections across Democracy and Autocracy (NELDA) database (Hyde and Marinov, 2011). The NELDA is a comprehensive database on national elections that provides precise information on the date and the conditions in which these elections are held. We compute the election index following Franzese (2000) : elec $=\frac{(m-1)+\frac{d}{D}}{12}$, where $m$ and $d$ are respectively the month and the day when the election takes place while $D$ is the number of days of month $m$. The preelectoral index is obtained as $1-$ elec. ${ }^{7}$ The election index allows to test more precisely for the opportunistic cycle because it captures whether, in a given year, the incumbent had sufficient time to manipulate public

\footnotetext{
${ }^{5}$ See Appendix $\mathrm{C}$ for detailed information about these rules. As relatively few developing countries have fiscal rules, the number of countries with rules in our sample is comparable to that of other studies, e.g. such as Tapsoba (2012). The majority of countries in the sample have combination of rules, which is why the total does not add to 13.

${ }^{6}$ Therefore, such a definition excludes, for instance, fiscal targets that are subject to regular revisions.

${ }^{7}$ We include the preelectoral year in some specifications but they were not statistically significant and do not change the main results. We also use the electoral year dummies and the results remain similar.
} 
spending before the election is held.

The macroeconomic controls are economic growth, trade openness, net public aid per capita, GDP per capita and the lagged public debt. Real economic growth from the WDI captures business cycle fluctuations (see, for instance, Shi and svensson, 2006). Since more open economies may have larger public expenditures in order to cope with a higher degree of vulnerability to risks and to provide for the associated higher need for social insurance (Rodrik, 1998), we control for trade openness. As foreign aid relaxes the government's budget constraint by giving access to additional resources, we account for it in our empirical analysis. We also control for real GDP per capita since a high income level may induce a greater demand for public services and, hence, have a positive effect on public spending (Wagner's Law). We control for the lagged public debt (as a share of GDP) because a high level of initial debt should, ceteris paribus ${ }_{i t}$, lead to a reduction in public spending in order to satisfy the constraint of public debt sustainability (Wyplosz, 2002; Gali and Perotti, 2003). ${ }^{8}$ We also control for sub-regional economic growth and global economic growth as proxies respetively for common shocks at sub-regional level and global macroeconomic trend.

In addition to the macroeconomic controls, we include government fragmentation and the orientation of the party in power (right wing ${ }_{i t}$ ). The data are from the Database of Political Institutions (DPI). Government fragmentation is the probability that two politicians picked at random from the legislature will be of different parties. According to the "common pool" theory (Alesina and Drazen, 1991; Velasco, 2000; Talvi and Vègh, 2005) countries with a fragmented government should have higher public expenditure. Fiscal rules can be viewed as a way of "tying the hands" of the government (Debrun et al., 2008) and, thus, the fragmentation of the government could be positively correlated with the adoption of fiscal rules. But fragmented governments may also be a determinant of the centralization of public expenditures (Jametti and Joanis, 2016). As the effect of centralization on the size of public spending is a priori ambiguous, the effect of government fragmentation on fiscal rule adoption is also a priori ambiguous.

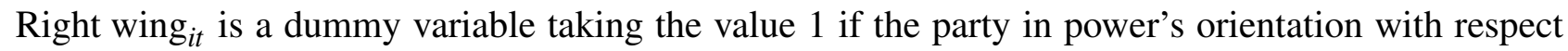

\footnotetext{
${ }^{8}$ Lagged public debt is also a potential determinant of fiscal rules (Tapsoba, 2012).
} 
to economic policy is defined as conservative, christian democratic or right-wing. It allows us to test for a partisan cycle. This variable may capture the fact that right wing governments are characterized by fiscal conservatism. While right wing governments may tend to display low levels of public spending, the effect of this variable on fiscal rule adoption is ambiguous a priori as right wing governments may exhibit self-discipline and thus may not need these rules despite being in favor of such rules. ${ }^{9}$

\section{Results}

We begin the presentation of our results by showing those pertaining to the first step of our empirical approach (that is the estimation of equation (2)). This first set of results documents the determinants of fiscal rule adoption. We then turn to our baseline results which correspond to the second step of our IV approach (the 'first-stage' equations (3) and (4)) and to the results of the 'second-stage' equation (1) using both OLS and IV. Finally, we present more detailed results related to the design of fiscal rules, the experience with rules and the cycle.

\subsection{Determinants of fiscal rule adoption}

Table 1 shows the results of the Probit estimation (equation 2), i.e. the first step of our empirical approach. First, it shows that the number of neighboring countries in the region with fiscal rules has a positive and statistically significant effect on the likelihood of a country to have these rules. This result is consistent with the diffusion mechanism that we outlined earlier and holds for the different types of fiscal rules in the sample. In addition, the results are also broadly consistent with previous empirical works for the other determinants of fiscal rules. In particular, a good macroeconomic performance is positively correlated with the adoption of fiscal rules (Calderón and Schmidt-Hebbel, 2008; Kumar et al., 2009; Tapsoba, 2012). For instance, economic growth (Columns 1 and 2) and GDP per capita (column 4) are positively correlated with the likelihood of having a balanced budget rule or an expenditure rule in place, respectively. High inflation is negatively correlated with the presence of fiscal rules. Foreign aid, which

\footnotetext{
${ }^{9}$ Note that the control variables are based on the determinants of public spending, that are also potential determinants of the adoption of fiscal rules (Calderón and Schmidt-Hebbel, 2008; Kumar et al., 2009; Tapsoba, 2012).
} 
relaxes the budget constraint of the government, is negatively correlated with the probability of having fiscal rules. Finally, Right wing governments have lower probability of adopting balanced budget rules and debt rules. These last two results, to our knowledge are novel.

[ Table 1 near here ]

\section{Baseline results}

We now turn to our results pertaining to the disciplining effect of fiscal rules (the usual focus of the literature on political budget cycles). The dependent variable here is the general government's public consumption. We provide estimations on all election years, "democratic" elections and elections that take place at constitutionally determined dates (hereafter, predetermined elections dates). Following Brender and Drazen (2005), elections are considered "democratic" for the years with positive scores on the Polity2 index.

Table 2 shows the first stage results (equations (3) and (4)), which correspond to the second stage estimates presented in Table 3. Again, since we have two endogenous variables (the fiscal rules dummy and the interaction term), there are two first stages. We instrument the interaction between election and fiscal rules by the interaction between election and the predicted probality $\hat{F R}$. Columns (1) to (3) show the first stage for the fiscal rule dummy (equation (3)) and Columns (4) to (6) show the first stage for the interaction term (equation (4)). Overall, all the instruments have a positive and statistically significant effect on the corresponding endogenous regressor consistently with the argument of regional diffusion of fiscal rules. The p values associated to Angrist and Pischke (2009) test allow us to reject the null of weak identification (at a 5\% level).

[ Table 2 near here ]

Table 3 shows the estimates of equation (1) using OLS and IV estimators. ${ }^{10}$ The results show that

\footnotetext{
${ }^{10}$ We show in Appendix D that political budget cycles in public consumption is present in our sample. The results show that these cycles are particularly strong during democratic and thus competitive elections consistently with the literature (see
} 
either considering all election years or democratic and "predetermined" election dates, fiscal rules have a negative and statistically significant effect on public consumption during election years. In addition, IV estimates of the effect of fiscal rules on polititical budget cycles are larger than OLS estimates. In column (1), the estimates suggest that, in election years with fiscal rules, public consumption is reduced by $0.45 \%$ point of GDP relatively to election years without such rules. On the other hand, the corresponding effect from IV estimates in column (2) shows a reduction by $1.65 \%$ point of GDP as compared to election years without rules. This impact is equivalent to a reduction by a third of the volatility of public consumption in our sample.

\section{[ Table 3 near here ]}

The fact that IV estimates are larger than OLS estimates suggests that controlling for an omitted variable bias is not enough to deal with the endogeneity problems and that OLS tend to overestimate the effects of fiscal rules. The overestimation (by OLS) is consistent with countries with good macroeconomic conditions being more likely to adopt fiscal rules (Calderón and Schmidt-Hebbel, 2008 ; Kumar et al., 2009 and Tapsoba, 2012) as shown in Table 1. Moreover, the magnitude of the effect (the coefficient on the interaction term being higher than the coefficient on election years in absolute terms) is an interesting result. It suggests that the political budget cycle in public spending may disappear ${ }_{i t}$ or that we may be in the presence of a fiscal discipline effect in election years when national fiscal rules are in place. Consistent with the theoretical result of Rose (2006) discussed above, fiscal rules neutralize the political budget cycle as the incumbent no longer derives an electoral advantage from fiscal policy manipulation. This discipline effect is novel because previous analyses (Ebeke and Ölçer, 2013)) only find a dampening effect.

Also, Table 3, column (4) shows the IV estimates focusing on the subsample of democratic elections. The effect of fiscal rules on the political budget cycle is larger than in column (2) that includes all elections. More specifically, public consumption is reduced by $2.46 \%$ point of GDP (while it is $1.65 \%$ point in the baseline). This result is consistent with Block (2002) and suggests that fiscal rules are more for instance Vergne (2009). 
effective in democracies. Indeed, the political costs of breaking these rules might be higher in democratic countries than in non democratic ones because of the uncertainty about the probability of reelection in the former. In addition, democracies are characterized by a constraint on the executive that may complement fiscal rules in constraining fiscal discretion.

\subsection{The design of fiscal rules, the experience with rules and the cycle}

Now, we explore the effects of the institutional design, the type of rules and also whether the effect of fiscal rules varies as they become more entrenched.

First, Table 4 below shows our results for the institutional characteristics of rules. Previous studies indeed suggest that the design of fiscal rules matter for their effectiveness. We consider features that may enhance the stringency of fiscal rules, such as the availability of a mechanism for monitoring their compliance outside the government and the level(s) of government covered by the rules (general government vs. central government only). Rules that are monitored by independent bodies outside the government because they are particularly stringent (Debrun et al., 2008; Schaechter et al., 2012; Nerlich and Reuter, 2013 and Debrun and Kinda, 2014) should be more successful in constraining political budget cycles. In particular, breaking rules that are monitored by independent bodies outside the government may impose high political costs (Debrun et al., 2008). The theoretical effect of rules that cover the general government is not clear a priori. Indeed, fiscal rules with this feature may loose in effectiveness by targeting fiscal aggregates that are controlled by different levels of government but are also considered more stringent (Debrun et al., 2008; Schaechter et al., 2012 and Nerlich and Reuter, 2013).

\section{[ Table 4 near here ]}

The results in Table 4 show that the monitoring of compliance outside the government and the coverage of the rule at the general government level matter for political budget cycles. ${ }^{11}$ The previous comparison between OLS and IV estimates still holds. In columns (2) and (4), the results show that pub-

\footnotetext{
${ }^{11}$ The monitoring of compliance outside the government is in place if the database reports that there is an independent council monitoring the compliance of a given rule.
} 
lic consumption is reduced by $1.88 \%$ point of GDP and $2.07 \%$ point of GDP in election years, with fiscal rules respectively featuring a monitoring of compliance outside the government and fiscal rules covering the general government. Nerlich and Reuter (2013) and Debrun and Kinda (2014) also find that fiscal rules are strengthened by independent bodies monitoring their compliance, and our results are consistent with fiscal rules covering the general government level being the most stringent (Schaechter et al., 2012). Also, the growing decentralization of public expenditures in developing countries is often seen as a threat to fiscal discipline (Fedelino and Ter-Minassian, 2010 and Joanis, 2014). Fiscal rules constraining all levels of governments may help achieve fiscal discipline.

Table 5 presents our results for the type of rules in place. We report the results for Balanced Budget Rules (BBR), Debt Rules (DR) and Expenditure Rules (ER). The OLS estimates show that BBR are the type of rules that matter most for fiscal discipline in election years, as the marginal effect is larger. In column (1), public consumption is reduced by $0.97 \%$ point of GDP in election years with BBR in place, while the effects for DR and ER are respectively $0.42 \%$ point of GDP and $0.39 \%$ point of GDP. These results are consistent with Rose (2006) who finds that stringent balanced budget rules dampen political budget cycles. In addition, they are also consistent with Bergman et al. (2016) who find that balanced budget rules are the most effective in reducing structural primary deficits in a sample of 27 EU countries. The IV estimates show much larger negative effects, but only expenditure rules display a statistically significant effect. ${ }^{12}$

[ Table 5 near here ]

Finally, we investigate the long term impact of rules by exploring the effect of fiscal rules conditionally on the rank of elections. It is reasonable to conjecture that these rules become more credible the longer they are in place. Table 6 shows the results. The IV and OLS estimates are similar in showing that

\footnotetext{
${ }^{12}$ Note that given the small sample variability, the IV results on the type of rules should be interpreted with caution. In column (6), the results show that public consumption is reduced by $2.44 \%$ points during election years with expenditure rules in place. The findings on expenditure rules are consistent with Cordes et al. (2015) who show that the compliance rate for these rules are high. Also, as mentioned earlier, these results are broadly consistent with the fact that expenditure rules (and balanced budget rules) constrain fiscal policy in the short run, thus they should be more relevant for budget cycles.
} 
the effect of fiscal rules are stronger for the second election ${ }^{13}$ than for the first election. Fiscal rules do not have a statistically significant effect for the first election. This suggests that fiscal rules may be more effective in constraining fiscal discretion as they become more entrenched and therefore more credible. IV estimates in Column (4) show that fiscal rules reduce public expenditure by $1.68 \%$ point of GDP in the second election.

[ Table 6 near here ]

\section{Robustness: testing for overidentifying restrictions}

In this section, we augment our previous empirical strategy by adding an instrumental variable which allows us to test for overidentification. We take advantage of a continuous measure of fiscal rules. We use the fiscal rule strength index of Schaechter et al. (2012). This 'stringency index' is based on key indicators of fiscal rules such as: the legal basis, the coverage, the existence of formal enforcement procedure, expenditure ceilings, fiscal responsibility laws and the existence of an independant body setting budget assumption and monitoring the budget implementation. ${ }^{14}$

Our additional instrumental variable follows Ayuso-i-Casals et al. (2007) in using the (one year) lagged value of the fiscal rule index to capture persistence in the legislative process. Indeed, in contrast to the dummy used so far, the index has the advantage to vary over time. We argue that the budget stance at a given time should not have an effect on the past strength of the rule; this instrument should therefore have an influence on current public expenditure only through its effect on the current strength of fiscal rules. In addition, we control for different variables capturing the macroeconomic condition (such as economic growth) that could possibly violate the exclusion restriction as discussed previously in section 1.1. Overall, we develop an instrumental variable strategy that combines our baseline approach (accounting for the endogeneity of the adoption) with the persitence of rules. Table 7 shows results that are similar to the baseline: Fiscal rules dampen the political budget cyle. In addition, in all specifications, we cannot

\footnotetext{
${ }^{13} \mathrm{We}$ focus on the first two elections since the adoption of fiscal rules because, in our sample, most of the rules are adopted over the last ten years of the period.

${ }^{14}$ For more details, see Schaechter et al. (2012).
} 
reject at any conventional level the null of the validity of overidentifying restrictions, and we reject the null of weak identification at all conventional level. Stated otherwise, this robustness tests confirms that fiscal rules have a causal effect on the political budget cycle. ${ }^{15}$

[ Table 7 near here ]

\section{Conclusion}

We have exploited the geographical pattern in the adoption of fiscal rules to empirically investigate whether the constraint that fiscal rules may impose on discretionary fiscal policy are binding during election years. Our empirical analysis provides a novel, robust identification strategy in order to estimate the causal effect of fiscal rules. Using a sample of developing countries, we find that fiscal rules matter for fiscal discipline. In addition, some specific features of fiscal rules are particularly relevant to achieve fiscal discipline: Expenditure rules, rules targeting all levels of government and rules that are monitored by an independent body outside the government lead to fiscal discipline over the electoral cycle. Furthermore, we also find that fiscal rules are more effective in constraining political budget cycles the longer they are in place.

Previous studies have emphasized that political budget cycles are a symptom of the divergence between political incentives and social welfare maximization and that the aggressive use of fiscal policy discretion induce macroeconomic volatility (Fatás and Mihov, 2003). Fiscal rules may therefore play an important role in reducing macroeconomic volatility by curbing politically motivated public expenditures in developing countries. An important message from our analysis is that their design, however, is crucial. For instance, our results suggest that escape clauses should be well defined in order to avoid changing or amending too often fiscal rules and thus undermining their credibility in the long run. Our findings also have interesting implications regarding the design of fiscal rules in increasingly decentralized developing countries, i.e. that fiscal rules might be more effective if they target the general government. Note how-

\footnotetext{
${ }^{15}$ Note however that the discipline effect that we have found using the fiscal rules dummy is not robust to the use of the index.
} 
ever that if fiscal rules are not well-designed to be flexible enough to accomodate cyclical fluctuations they may constrain the ability of fiscal policy to smooth business cyles. 


\section{References}

[1] Abbas, S. M., Belhocine, N., ElGanainy, A. A., \& Horton, M. (2010). "A historical public debt database”. International Monetary Fund Working Paper, (WP/10/245).

[2] Alesina, A., \& Drazen, A. (1991). “Why are stabilizations delayed?”. American Economic Review, 81(5), 1170-1188.

[3] Angrist, J.D. \& Pischke, J.-S. 2009. “Mostly Harmless Econometrics: An Empiricist's Companion”. Princeton: Princeton University Press.

[4] Ayuso-i-Casals, J., Debrun, X., Kumar, M. S., Moulin, L., \& Turrini, A., (2007). "Beyond the SGP - Features and effects of EU national-level numerical fiscal rules", mimeo.

[5] Beck, T., Clarke, G., Groff, A., Keefer, P., \& Walsh, P. (2001). "New tools in comparative political economy: The Database of Political Institutions". The World Bank Economic Review, 15(1), 165176.

[6] Bergman, U. M., Hutchison, M. M., \& Jensen, S. E. H. (2016). "Promoting sustainable public finances in the European Union: The role of fiscal rules and government efficiency". European Journal of Political Economy, 44, 1-19.

[7] Block, S. A. (2002). "Political business cycles, democratization, and economic reform: the case of Africa”. Journal of Development Economics, 67(1), 205-228.

[8] Bonfatti, A., \& Forni, L. (2019). "Fiscal rules to tame the political budget cycle: Evidence from Italian municipalities". European Journal of Political Economy.

[9] Brender, A. (2003). “The effect of fiscal performance on local government election results in Israel: 1989-1998”. Journal of Public Economics, 87(9), 2187-2205.

[10] Brender, A., \& Drazen, A. (2005). "Political budget cycles in new versus established democracies". Journal of Monetary Economics, 52(7), 1271-1295. 
[11] Brueckner, J. K. (2003). "Strategic Interaction Among Governments: An Overview of Empirical Studies”. International Regional Science Review, 26(2), 175-188.

[12] Calderón, C., \& Hebbel, K. S. (2008). “The choice of fiscal regimes in the world". Documentos de Trabajo (Banco Central de Chile), (487), 1.

[13] Caselli, F. G., \& Reynaud, J. (2019). "Do Fiscal Rules Cause Better Fiscal Balances? A New Instrumental Variable Strategy”. International Monetary Fund Working Paper, (WP/19/49).

[14] Cordes, T., Kinda, M. T., Muthoora, M. P. S., \& Weber, A. (2015). "Expenditure Rules: Effective Tools for Sound Fiscal Policy?” International Monetary Fund Working Paper, (No 15-29).

[15] Debrun, X., Moulin, L., Turrini, A., Ayuso-i-Casals, J., \& Kumar, M. S. (2008). “Tied to the mast? National fiscal rules in the European Union.” Economic Policy, 23(54), 298-362.

[16] Debrun, M. X., \& Kinda, M. T. (2014). "Strengthening Post-Crisis Fiscal Credibility: Fiscal Councils on the Rise-A New Dataset” International Monetary Fund Working Paper, (No 14-58).

[17] Ebeke, C., \& Ölçer, D. (2013). "Fiscal policy over the election cycle in low-income countries", International Monetary Fund Working Paper, (No 13-153).

[18] Eklou, K. (2018). "Essais sur les conséquences des chocs de revenus tirés des ressources naturelles: le cas des finances publiques et de l'économie politique".

[19] Fatás, A., \& Mihov, I. (2003). “The Case For Restricting Fiscal Policy Discretion”. The Quarterly Journal of Economics, 118(4), 1419-1447.

[20] Fatás, A., \& Mihov, I. (2006). “The macroeconomic effects of fiscal rules in the US states”. Journal of Public Economics, 90(1), 101-117.

[21] Fedelino, A. \& Ter-Minassian, T. (2010). "Making fiscal decentralization work: cross-country experiences". International Monetary Fund.

[22] Franzese, R. J. (2000). "Electoral and partisan manipulation of public debt in developed democracies, 1956-1990”. In R. Strauch and J. Von Hagen (Eds.), Institutions, Politics and Fiscal Policy, pp. 61-83. Kluwer Academic Press. 
[23] Gali, J. \& Perotti, R. (2003) "Fiscal Policy and Monetary Integration in Europe" Economic Policy, $18(37), 533-572$.

[24] Grembi, V., Nannicini, T., \& Troiano, U. (2016). "Do fiscal rules matter?" American Economic Journal: Applied Economics, 8(3), 1-30.

[25] Hyde, S. D., \& Marinov, N. (2011). “Which elections can be lost?”. Political Analysis, 20(2), 191210.

[26] Jametti, M., \& Joanis, M. (2016). "Electoral Competition as a Determinant of Fiscal Decentralisation”. Fiscal Studies, 37(2), 285-300.

[27] Joanis, M. (2014). "Shared Accountability and Partial Decentralization in Local Public Good Provision”. Journal of Development Economics, 107, 28-37.

[28] Keefer, P. (2010). "Database on Political Institutions (DPI2010)". Development Research Group, (Washington: The World Bank).

[29] Kopits G., \& Symansky S., (1998), "Fiscal Policy Rules”, IMF Occasional Paper, No.162.

[30] Krogstrup, S., \& Wälti, S. (2008). “Do fiscal rules cause budgetary outcomes?”. Public Choice, 136(1-2), 123-138.

[31] Kumar, M. S., Baldacci, E. , Schechter, A. , Caceres, C., Kim, D., Debrun, X., Escolano, J., Jonas, J., Karam, P., Yakadina, I., \& Zymek, R., (2009). "Fiscal Rules-Anchoring Expectations for Sustainable Public Finances", IMF Staff Papers.

[32] Marshall, M. \& Jaggers, K., (2005). “Polity IV: Dataset Users’ Manual”. Center for Global Policy, George Mason University.

[33] Nerlich, C., \& Reuter, W. H. (2013). "The design of national fiscal frameworks and their budgetary impact”. European Central Bank Working Paper, 1588.

[34] Pitlik, H. (2007). "A race to liberalization? Diffusion of economic policy reform among OECD economies" Public Choice, 132(1), 159-178. 
[35] Poterba, J. M. (1996). "Budget Institution and fiscal policy in US States". American Economic Review, 86(2): 395-400.

[36] Rodrik, D. (1998). “Why Do More Open Economies Have Bigger Governments?”. The Journal of Political Economy, 106(5), 997-1032.

[37] Rogoff, K. S. (1990). “Equilibrium Political Budget Cycles”. American Economic Review, 80, 2136.

[38] Rogoff, K., \& Sibert, A. (1988). "Elections and macroeconomic policy cycles". The review of economic studies, 55(1), 1-16.

[39] Rose, S. (2006). "Do fiscal rules dampen the political business cycle?". Public choice, 128(3-4), 407-431.

[40] Sanderson, E., \& Windmeijer, F. (2016). "A weak instrument F-test in linear IV models with multiple endogenous variables." Journal of Econometrics, 190(2), 212-221.

[41] Schaechter, A., Kinda, T., Budina, N. T., \& Weber, A. (2012). "Fiscal Rules in Response to the Crisis-Toward the “Next-Generation” Rules: A New Dataset”. International Monetary Fund Working Paper, WP/12/187.

[42] Shi, M., \& Svensson, J. (2006). "Political budget cycles: Do they differ across countries and why?" Journal of Public Economics, 90(8), 1367-1389.

[43] Schuknecht, L. (2000). "Fiscal policy cycles and public expenditure in developing countries." Public Choice, 102(1-2), 113-128.

[44] Talvi, E., \& Végh, C. A. (2005). "Tax base variability and procyclical fiscal policy in developing countries". Journal of Development Economics, 78(1), 156-190.

[45] Tapsoba, R. (2012). "Do National Numerical Fiscal Rules really shape fiscal behaviours in developing countries? A treatment effect evaluation”. Economic Modelling, 29(4), 1356-1369.

[46] Velasco, A. (2000). "Debts and deficits with fragmented fiscal policymaking". Journal of Public Economics, 76(1), 105-125. 
[47] Vergne, C. (2009). "Democracy, elections and allocation of public expenditures in developing countries”. European Journal of Political Economy, 25(1), 63-77.

[48] Wooldridge, J. M. (2010). "Econometric analysis of cross section and panel data". MIT press.

[49] Wyplosz, C. (2002). "Fiscal Policy: Institutions versus Rules". CEPR Discussion Papers 3238, CEPR Discussion Papers. 


\section{Tables}

Table 1: Determinants of fiscal rule adoption

\begin{tabular}{|c|c|c|c|c|}
\hline & $\begin{array}{l}\text { (1) } \\
\text { FR }\end{array}$ & $\begin{array}{c}(2) \\
\text { BBR }\end{array}$ & $\begin{array}{l}\text { (3) } \\
\text { DR }\end{array}$ & $\begin{array}{l}(4) \\
\text { ER }\end{array}$ \\
\hline Neighbors & $\begin{array}{c}0.205 * * * \\
(0.062)\end{array}$ & $\begin{array}{c}0.200 * * * \\
(0.073)\end{array}$ & $\begin{array}{c}0.256 * * * \\
(0.069)\end{array}$ & $\begin{array}{c}\mathbf{0 . 2 9 6} * * * \\
(\mathbf{0 . 0 8 1})\end{array}$ \\
\hline Elec & $\begin{array}{c}0.250 \\
(0.242)\end{array}$ & $\begin{array}{l}-0.049 \\
(0.166)\end{array}$ & $\begin{array}{c}0.506^{* *} \\
(0.212)\end{array}$ & $\begin{array}{l}-0.041 \\
(0.274)\end{array}$ \\
\hline Growth & $\begin{array}{c}0.037 * * \\
(0.016)\end{array}$ & $\begin{array}{c}0.047 * * * \\
(0.017)\end{array}$ & $\begin{array}{c}0.002 \\
(0.021)\end{array}$ & $\begin{array}{c}0.037 \\
(0.023)\end{array}$ \\
\hline Openness (Log) & $\begin{array}{l}-0.116 \\
(0.304)\end{array}$ & $\begin{array}{l}-0.163 \\
(0.379)\end{array}$ & $\begin{array}{l}-0.008 \\
(0.260)\end{array}$ & $\begin{array}{c}-0.903 * * \\
(0.423)\end{array}$ \\
\hline Inflation (Log) & $\begin{array}{c}-2.091 * * \\
(0.906)\end{array}$ & $\begin{array}{l}-1.935^{*} \\
(1.125)\end{array}$ & $\begin{array}{c}-1.809 * * \\
(0.910)\end{array}$ & $\begin{array}{l}-3.298 \\
(2.219)\end{array}$ \\
\hline Aid (Log) & $\begin{array}{c}-0.353^{* * *} * \\
(0.119)\end{array}$ & $\begin{array}{c}-0.341 * * * \\
(0.126)\end{array}$ & $\begin{array}{c}-0.274 * * \\
(0.113)\end{array}$ & $\begin{array}{l}-0.167 \\
(0.179)\end{array}$ \\
\hline Govern Fragmentation & $\begin{array}{l}-0.447 \\
(0.445)\end{array}$ & $\begin{array}{l}-0.562 \\
(0.449)\end{array}$ & $\begin{array}{c}0.234 \\
(0.597)\end{array}$ & $\begin{array}{l}-0.453 \\
(0.919)\end{array}$ \\
\hline Right wing & $\begin{array}{l}-0.288 \\
(0.281)\end{array}$ & $\begin{array}{c}-0.476^{*} \\
(0.271)\end{array}$ & $\begin{array}{c}-1.179 * * \\
(0.475)\end{array}$ & $\begin{array}{c}0.099 \\
(0.363)\end{array}$ \\
\hline Public Debt (Log) $(\mathrm{t}-1)$ & $\begin{array}{l}-0.411 \\
(0.298)\end{array}$ & $\begin{array}{l}-0.121 \\
(0.344)\end{array}$ & $\begin{array}{l}-0.040 \\
(0.326)\end{array}$ & $\begin{array}{l}-0.704 \\
(0.478)\end{array}$ \\
\hline GDP Per Capita (log) & $\begin{array}{l}-0.107 \\
(0.172)\end{array}$ & $\begin{array}{l}-0.092 \\
(0.198)\end{array}$ & $\begin{array}{l}-0.228 \\
(0.181)\end{array}$ & $\begin{array}{c}0.703 * * * \\
(0.203)\end{array}$ \\
\hline Constant & $\begin{array}{c}11.887 * * * \\
(4.257)\end{array}$ & $\begin{array}{c}9.855^{* *} \\
(4.824)\end{array}$ & $\begin{array}{l}8.693^{*} \\
(4.856)\end{array}$ & $\begin{array}{c}14.094 \\
(12.274)\end{array}$ \\
\hline Observations & 1190 & 1190 & 1190 & 1190 \\
\hline Countries & 67 & 67 & 67 & 67 \\
\hline
\end{tabular}

Notes: Clustered Standard errors at country level in parentheses. FR $=$ Fiscal rules dummy (all types), BBR $=$ Balanced Budget Rules, $\mathrm{DR}=$ Debt Rules and ER= Expenditure Rules. Clustered Standard errors at country level in parentheses. * $p<0.10, * * p<0.05, * * * p<0.01$. 
Table 2: First stages

\begin{tabular}{|c|c|c|c|c|c|c|}
\hline & $\begin{array}{c}(1) \\
\text { Base }\end{array}$ & $\begin{array}{c}(2) \\
\text { Dem }\end{array}$ & $\begin{array}{c}(3) \\
\text { Pred }\end{array}$ & $\begin{array}{c}(4) \\
\text { Base }\end{array}$ & $\begin{array}{c}(5) \\
\text { Dem }\end{array}$ & $\begin{array}{c}(6) \\
\text { Pred }\end{array}$ \\
\hline$\hat{F R}$ & $\begin{array}{c}\text { 0.714** } \\
(\mathbf{0 . 2 8 8})\end{array}$ & $\begin{array}{c}\mathbf{0 . 8 4 4} * * \\
(\mathbf{0 . 3 7 1})\end{array}$ & $\begin{array}{c}0.737 * * \\
(0.305)\end{array}$ & $\begin{array}{l}-0.021 \\
(0.050)\end{array}$ & $\begin{array}{c}0.032 \\
(0.061)\end{array}$ & $\begin{array}{c}-0.026 \\
(0.087)\end{array}$ \\
\hline Elec $\times \hat{F R}$ & $\begin{array}{c}-0.216 \\
(0.203)\end{array}$ & $\begin{array}{l}-0.206 \\
(0.244)\end{array}$ & & $\begin{array}{c}0.762 * * \\
(0.366)\end{array}$ & $\begin{array}{c}\mathbf{0 . 8 1 0} * * \\
(\mathbf{0 . 4 1 2})\end{array}$ & \\
\hline Predet Elec $\times \hat{F R}$ & & & $\begin{array}{l}-0.160 \\
(0.218)\end{array}$ & & & $\begin{array}{c}1.137 * * \\
(0.492)\end{array}$ \\
\hline Elec & $\begin{array}{l}-0.005 \\
(0.011)\end{array}$ & $\begin{array}{l}-0.011 \\
(0.013)\end{array}$ & & $\begin{array}{c}0.026 \\
(0.038)\end{array}$ & $\begin{array}{c}0.022 \\
(0.039)\end{array}$ & \\
\hline Growth & $\begin{array}{c}-0.003 * * \\
(0.001)\end{array}$ & $\begin{array}{c}-0.005^{* *} \\
(0.002)\end{array}$ & $\begin{array}{c}-0.003 * * \\
(0.001)\end{array}$ & $\begin{array}{c}-0.001 * \\
(0.000)\end{array}$ & $\begin{array}{c}-0.001 * \\
(0.001)\end{array}$ & $\begin{array}{c}0.000 \\
(0.001)\end{array}$ \\
\hline Openness (Log) & $\begin{array}{c}0.029 \\
(0.058)\end{array}$ & $\begin{array}{c}0.120 \\
(0.099)\end{array}$ & $\begin{array}{c}0.027 \\
(0.061)\end{array}$ & $\begin{array}{c}-0.003 \\
(0.010)\end{array}$ & $\begin{array}{c}0.007 \\
(0.017)\end{array}$ & $\begin{array}{c}-0.005 \\
(0.014)\end{array}$ \\
\hline Inflation (Log) & $\begin{array}{l}0.015^{*} \\
(0.008)\end{array}$ & $\begin{array}{c}0.013 \\
(0.014)\end{array}$ & $\begin{array}{l}0.016^{*} \\
(0.009)\end{array}$ & $\begin{array}{c}0.002 \\
(0.004)\end{array}$ & $\begin{array}{c}0.001 \\
(0.007)\end{array}$ & $\begin{array}{c}0.005 \\
(0.006)\end{array}$ \\
\hline Aid (Log) & $\begin{array}{c}0.039 * * \\
(0.017)\end{array}$ & $\begin{array}{c}0.058 * * * \\
(0.022)\end{array}$ & $\begin{array}{c}0.039 * * \\
(0.017)\end{array}$ & $\begin{array}{c}0.003 \\
(0.004)\end{array}$ & $\begin{array}{c}0.006 \\
(0.005)\end{array}$ & $\begin{array}{c}0.010^{*} \\
(0.006)\end{array}$ \\
\hline Govern Fragmentation & $\begin{array}{c}0.036 \\
(0.059)\end{array}$ & $\begin{array}{c}0.050 \\
(0.078)\end{array}$ & $\begin{array}{c}0.039 \\
(0.061)\end{array}$ & $\begin{array}{c}-0.006 \\
(0.013)\end{array}$ & $\begin{array}{c}-0.000 \\
(0.016)\end{array}$ & $\begin{array}{c}-0.003 \\
(0.016)\end{array}$ \\
\hline Right wing & $\begin{array}{l}-0.011 \\
(0.036)\end{array}$ & $\begin{array}{l}-0.004 \\
(0.041)\end{array}$ & $\begin{array}{l}-0.010 \\
(0.038)\end{array}$ & $\begin{array}{l}0.011^{*} \\
(0.006)\end{array}$ & $\begin{array}{c}0.011 \\
(0.007)\end{array}$ & $\begin{array}{c}0.035^{* *} \\
(0.015)\end{array}$ \\
\hline Public Debt (Log) $(\mathrm{t}-1)$ & $\begin{array}{c}0.027 \\
(0.024)\end{array}$ & $\begin{array}{c}0.034 \\
(0.032)\end{array}$ & $\begin{array}{c}0.026 \\
(0.026)\end{array}$ & $\begin{array}{c}0.014 * * \\
(0.007)\end{array}$ & $\begin{array}{c}0.011 \\
(0.009)\end{array}$ & $\begin{array}{c}0.024 \\
(0.015)\end{array}$ \\
\hline GDP Per Capita (log) & $\begin{array}{c}0.119 \\
(0.103)\end{array}$ & $\begin{array}{c}0.159 \\
(0.191)\end{array}$ & $\begin{array}{c}0.115 \\
(0.109)\end{array}$ & $\begin{array}{c}0.045 * * \\
(0.022)\end{array}$ & $\begin{array}{c}0.067 * \\
(0.036)\end{array}$ & $\begin{array}{c}-0.012 \\
(0.032)\end{array}$ \\
\hline Predet Elec & & & $\begin{array}{l}-0.005 \\
(0.012)\end{array}$ & & & $\begin{array}{c}0.005 \\
(0.047)\end{array}$ \\
\hline Endogenous Elec & & & $\begin{array}{c}-0.047 * * \\
(0.024)\end{array}$ & & & $\begin{array}{c}0.053 \\
(0.046)\end{array}$ \\
\hline Observations & 1190 & 768 & 1146 & 1190 & 768 & 1146 \\
\hline $\begin{array}{l}\text { Countries } \\
\mathrm{p} \text { value } \mathrm{F} \text { first Stage }(\text { fiscal rules) }\end{array}$ & $\begin{array}{c}67 \\
0.014\end{array}$ & $\begin{array}{c}51 \\
0.026\end{array}$ & $\begin{array}{c}64 \\
0.017\end{array}$ & 67 & 51 & 64 \\
\hline $\mathrm{p}$ value $\mathrm{F}$ first stage (Interaction) ${ }^{c}$ & & & & 0.007 & 0.003 & 0.007 \\
\hline
\end{tabular}

Notes: All Specifications include country-specific linear trends. The within estimator is used to eliminate the country fixed effects. Columns (1)-(3) show the first stage for fiscal rules and Columns (4)-(6) show the first stage for the interaction term. We instrument the interaction between election and fiscal rules by the interaction between election and the predicted probality $\hat{F R}$. Clustered Standard errors at country level in parentheses. Base $=$ "all elections", Dem= "democratic elections" and Pred = "Predetermined election dates".

c: F test Angrist and Pischke (2009) for excluded instruments with H0: "weak identification". * $p<0.10$, ** $p<0.05,{ }^{* * *} p<0.01$. 
Table 3: Baseline results

\begin{tabular}{|c|c|c|c|c|c|c|}
\hline & $\begin{array}{c}(1) \\
\text { Base (OLS) }\end{array}$ & $\begin{array}{c}(2) \\
\text { Base (IV) }\end{array}$ & $\begin{array}{c}(3) \\
\operatorname{Dem}(\mathrm{OLS})\end{array}$ & $\begin{array}{c}\text { (4) } \\
\text { Dem (IV) }\end{array}$ & $\begin{array}{c}(5) \\
\text { Pred (OLS) }\end{array}$ & $\begin{array}{c}(6) \\
\text { Pred (IV) }\end{array}$ \\
\hline Elec $\times$ FR & $\begin{array}{c}-1.032 * * * \\
(0.349)\end{array}$ & $\begin{array}{c}-2.360 * \\
(1.259)\end{array}$ & $\begin{array}{c}-1.063 * * * \\
(0.289)\end{array}$ & $\begin{array}{c}-3.506 * * \\
(1.567)\end{array}$ & & \\
\hline Predet Elec $\times$ FR & & & & & $\begin{array}{c}-0.676 * * * \\
(0.241)\end{array}$ & $\begin{array}{l}-2.025 * \\
(1.057)\end{array}$ \\
\hline FR & $\begin{array}{l}-0.225 \\
(0.761)\end{array}$ & $\begin{array}{c}1.960 \\
(3.100)\end{array}$ & $\begin{array}{l}-0.394 \\
(0.913)\end{array}$ & $\begin{array}{c}1.144 \\
(2.746)\end{array}$ & $\begin{array}{l}-0.223 \\
(0.775)\end{array}$ & $\begin{array}{c}1.077 \\
(2.836)\end{array}$ \\
\hline Predet Elec & & & & & $\begin{array}{c}0.503 * * \\
(0.243)\end{array}$ & $\begin{array}{c}0.646^{* *} \\
(0.313)\end{array}$ \\
\hline Endogenous Elec & & & & & $\begin{array}{c}0.835 \\
(0.511)\end{array}$ & $\begin{array}{l}0.932 * \\
(0.516)\end{array}$ \\
\hline Elec & $\begin{array}{c}0.579 * * * \\
(0.214)\end{array}$ & $\begin{array}{c}0.714 * * \\
(0.285)\end{array}$ & $\begin{array}{c}0.770 * * * \\
(0.231)\end{array}$ & $\begin{array}{c}1.041^{* * * *} \\
(0.312)\end{array}$ & & \\
\hline Observations & 1190 & 1190 & 768 & 768 & 1146 & 1146 \\
\hline $\begin{array}{l}\text { Countries } \\
\mathrm{p} \text { value } \mathrm{F} \text { first Stage }(\text { fiscal rules) } \\
\mathrm{p} \text { value } \mathrm{F} \text { first stage }(\text { Interaction })^{c}\end{array}$ & 67 & $\begin{array}{c}67 \\
0.014 \\
0.007\end{array}$ & 51 & $\begin{array}{c}51 \\
0.026 \\
0.003\end{array}$ & 64 & $\begin{array}{c}64 \\
0.017 \\
0.007\end{array}$ \\
\hline
\end{tabular}

Notes: All Specifications include country-specific linear trends and the set of control variables. The within estimator is used to eliminate the country fixed effects. FR= Fiscal rules dummy (all types). Columns (1)-(2) show estimates for all elections and Pred = "Predetermined election dates". Columns (3)-(4) show estimates on the subsample of democratic countries and Columns (5)-(6) take into account the endogeneity of the electoral calendar. c: F test Angrist and Pischke (2009) for excluded instruments with H0: "weak identification". * $p<0.10$, ** $p<0.05$, *** $p<0.01$. 
Table 4: Institutional features of the rules

\begin{tabular}{|c|c|c|c|c|}
\hline & $\begin{array}{c}(1) \\
\mathrm{MOG}(\mathrm{OLS})\end{array}$ & $\begin{array}{c}(2) \\
\text { MOG (IV) }\end{array}$ & $\begin{array}{c}(3) \\
\text { GG (OLS) }\end{array}$ & $\begin{array}{c}(4) \\
\text { GG (IV) }\end{array}$ \\
\hline Elec $\times$ FR & $\begin{array}{c}-1.088 * * * \\
(0.418)\end{array}$ & $\begin{array}{c}-2.636 * * \\
(1.280)\end{array}$ & $\begin{array}{c}-1.809 * * * \\
(0.553)\end{array}$ & $\begin{array}{c}-2.911 * * \\
(1.406)\end{array}$ \\
\hline Elec & $\begin{array}{c}0.681 * * * \\
(0.228)\end{array}$ & $\begin{array}{c}0.760 * * * \\
(0.232)\end{array}$ & $\begin{array}{c}0.680 * * * \\
(0.297)\end{array}$ & $0.841 * * *$ \\
\hline FR & $\begin{array}{l}-0.992 \\
(0.966)\end{array}$ & $\begin{array}{c}1.528 \\
(4.284)\end{array}$ & $\begin{array}{l}-2.054 \\
(1.623)\end{array}$ & $\begin{array}{c}7.693 \\
(14.066)\end{array}$ \\
\hline $\begin{array}{l}\text { Observations } \\
\text { Countries } \\
\mathrm{p} \text { value F first Stage (fiscal rules) } \\
\mathrm{p} \text { value F first stage }(\text { Interaction) }\end{array}$ & $\begin{array}{c}1029 \\
59\end{array}$ & $\begin{array}{c}1029 \\
59 \\
0.044 \\
0.000\end{array}$ & $\begin{array}{c}1002 \\
58\end{array}$ & $\begin{array}{c}1002 \\
58 \\
0.08 \\
0.03\end{array}$ \\
\hline
\end{tabular}

Notes: All Specifications include country-specific linear trends and the set of control variables. The within estimator is used to eliminate the country fixed effects. FR= Fiscal rules dummy (all types), MOG: "Monitoring of compliance Outside the Government" and GG: "General Government". c: F test Angrist and Pischke (2009) for excluded instruments. ${ }^{*} p<0.10,{ }^{* *} p<0.05,{ }^{* * *} p<0.01$. 
Table 5: Type of rules

\begin{tabular}{|c|c|c|c|c|c|c|}
\hline & $\begin{array}{l}(1) \\
\text { OLS }\end{array}$ & $\begin{array}{l}\text { (2) } \\
\text { IV }\end{array}$ & $\begin{array}{l}(3) \\
\text { OLS }\end{array}$ & $\begin{array}{l}(4) \\
\text { IV }\end{array}$ & $\begin{array}{l}(5) \\
\text { OLS }\end{array}$ & $\begin{array}{l}\text { (6) } \\
\text { IV }\end{array}$ \\
\hline Elec $\times$ BBR & $\begin{array}{c}-1.514 * * * \\
(0.401)\end{array}$ & $\begin{array}{l}-4.176 \\
(2.711)\end{array}$ & & & & \\
\hline Elec $\times$ DR & & & $\begin{array}{l}-0.975 * * * \\
(0.298)\end{array}$ & $\begin{array}{l}-4.232 \\
(3.173)\end{array}$ & & \\
\hline Elec $\times$ ER & & & & & $\begin{array}{l}-0.886 * \\
(0.526)\end{array}$ & $\begin{array}{r}-3.036 * \\
(1.732)\end{array}$ \\
\hline Elec & $\begin{array}{c}0.546 * * * \\
(0.205)\end{array}$ & $\begin{array}{c}0.659 * * \\
(0.268)\end{array}$ & $\begin{array}{c}0.552 * * * \\
(0.208)\end{array}$ & $\begin{array}{c}0.764 * * \\
(0.328)\end{array}$ & $\begin{array}{c}0.498^{* *} \\
(0.207)\end{array}$ & $\begin{array}{c}0.601 * * \\
(0.244)\end{array}$ \\
\hline BBR & $\begin{array}{c}0.750 \\
(0.705)\end{array}$ & $\begin{array}{c}2.744 \\
(4.304)\end{array}$ & & & & \\
\hline DR & & & $\begin{array}{c}1.363 \\
(0.937)\end{array}$ & $\begin{array}{c}3.255 \\
(4.340)\end{array}$ & & \\
\hline ER & & & & & $\begin{array}{c}-2.267 * * \\
(0.954)\end{array}$ & $\begin{array}{c}3.838 \\
(6.831)\end{array}$ \\
\hline Observations & 1190 & 1190 & 1190 & 1190 & 1190 & 1190 \\
\hline $\begin{array}{l}\text { Countries } \\
\mathrm{p} \text { value } \mathrm{F} \text { first Stage }(\text { fiscal rules) }\end{array}$ & 67 & $\begin{array}{c}67 \\
0.047\end{array}$ & 67 & $\begin{array}{c}67 \\
0.003\end{array}$ & 67 & $\begin{array}{c}67 \\
0.043\end{array}$ \\
\hline $\mathrm{p}$ value $\mathrm{F}$ first stage (Interaction) $)^{c}$ & & 0.068 & & 0.032 & & 0.062 \\
\hline
\end{tabular}

Notes: All Specifications include country-specific linear trends and the set of control variables. The within estimator is used to eliminate the country fixed effects. BBR $=$ Blanced Budget Rules, DR $=$ Debt Rules and ER= Expenditure Rules. Clustered Standard errors at country level in parentheses. c: F test Angrist and Pischke (2009) for excluded instruments. $* p<0.10, * * p<0.05, * * * p<0.01$. 
Table 6: The long term impact of fiscal rules

\begin{tabular}{|c|c|c|c|c|}
\hline & $\begin{array}{c}(1) \\
\text { FR1(OLS) }\end{array}$ & $\begin{array}{c}(2) \\
\text { FR2(OLS) }\end{array}$ & $\begin{array}{c}(3) \\
\text { FR1(IV) }\end{array}$ & $\begin{array}{c}(4) \\
\text { FR2(IV) }\end{array}$ \\
\hline $\mathbf{E l e c}_{1} \times \mathbf{F R}$ & $\begin{array}{l}-0.799 \\
(0.612)\end{array}$ & & $\begin{array}{l}-1.893 \\
(2.677)\end{array}$ & \\
\hline Elec $_{2} \times \mathbf{F R}$ & & $\begin{array}{l}-1.339 * \\
(0.712)\end{array}$ & & $\begin{array}{c}-2.237 * * * * \\
(0.585)\end{array}$ \\
\hline Elec & $\begin{array}{c}0.523 * * \\
(0.204)\end{array}$ & $\begin{array}{c}0.520 * * \\
(0.205)\end{array}$ & $\begin{array}{c}0.587 * * \\
(0.230)\end{array}$ & $\begin{array}{c}0.554 * * * \\
(0.203)\end{array}$ \\
\hline FR & $\begin{array}{l}-0.255 \\
(0.807)\end{array}$ & $\begin{array}{l}-0.348 \\
(0.760)\end{array}$ & $\begin{array}{c}1.514 \\
(3.368)\end{array}$ & $\begin{array}{c}1.570 \\
(2.978)\end{array}$ \\
\hline Observations & 1190 & 1190 & 1190 & 1190 \\
\hline $\begin{array}{l}\text { Countries } \\
p \text { value } F \text { first Stage (fiscal rules) })^{c} \\
p \text { value } F \text { first stage }(\text { Interaction) })^{c}\end{array}$ & 67 & 67 & $\begin{array}{c}67 \\
0.007 \\
0.000\end{array}$ & $\begin{array}{c}67 \\
0.013 \\
0.000\end{array}$ \\
\hline
\end{tabular}

Notes: All Specifications include country-specific linear trends and the set of control variables. The within estimator is used to eliminate the country fixed effects. FR= Fiscal rules dummy (all types). Elec 1 and Elec 2 are respectively the first and the second election held while fiscal rules were in place. The indices 1 and 2 for the fiscal rules denote the first and the second election respectively. Clustered Standard errors at country level in parentheses. c: F test Angrist and Pischke (2009) for excluded instruments with H0: "weak identification". * $p<0.10$, ** $p<0.05$, *** $p<0.01$. 
Table 7: Testing for overidentifying restrictions

\begin{tabular}{|c|c|c|c|c|c|c|c|c|c|}
\hline & $\begin{array}{c}(1) \\
\text { Base (OLS) }\end{array}$ & $\begin{array}{c}(2) \\
\text { (Base }(2 \mathrm{SLS})\end{array}$ & $\begin{array}{c}(3) \\
\text { Base (LIML) }\end{array}$ & $\begin{array}{c}(4) \\
\text { Dem (OLS) }\end{array}$ & $\begin{array}{c}(5) \\
\text { Dem }(2 S L S)\end{array}$ & $\begin{array}{c}(6) \\
\text { Dem (LIML) }\end{array}$ & $\begin{array}{c}(7) \\
\text { Pred (OLS) }\end{array}$ & $\begin{array}{c}(8) \\
\text { Pred }(2 S L S)\end{array}$ & $\begin{array}{c}(9) \\
\text { Pred (LIML) }\end{array}$ \\
\hline Elec $\times$ FR index & $\begin{array}{c}-0.304 * * * \\
(0.112)\end{array}$ & $\begin{array}{c}-0.224 * * \\
(0.113)\end{array}$ & $\begin{array}{c}-0.224 * * \\
(0.113)\end{array}$ & $\begin{array}{c}-0.236 * * \\
(0.112)\end{array}$ & $\begin{array}{l}-0.182 * \\
(0.111)\end{array}$ & $\begin{array}{l}-0.182 * \\
(0.111)\end{array}$ & & & \\
\hline Predet Elec $\times$ FR index & & & & & & & $\begin{array}{c}-0.306 * * * \\
(0.110)\end{array}$ & $\begin{array}{c}-0.225 * * \\
(0.111)\end{array}$ & $\begin{array}{c}-0.225 * * \\
(0.111)\end{array}$ \\
\hline FR index & $\begin{array}{c}0.106 \\
(0.314)\end{array}$ & $\begin{array}{c}0.037 \\
(0.453)\end{array}$ & $\begin{array}{c}0.037 \\
(0.454)\end{array}$ & $\begin{array}{l}-0.035 \\
(0.338)\end{array}$ & $\begin{array}{l}-0.257 \\
(0.499)\end{array}$ & $\begin{array}{l}-0.258 \\
(0.500)\end{array}$ & $\begin{array}{c}0.101 \\
(0.311)\end{array}$ & $\begin{array}{c}0.025 \\
(0.447)\end{array}$ & $\begin{array}{c}0.025 \\
(0.448)\end{array}$ \\
\hline Predet Elec & & & & & & & $\begin{array}{c}0.526^{* *} \\
(0.251)\end{array}$ & $\begin{array}{c}0.506^{* *} \\
(0.254)\end{array}$ & $\begin{array}{c}0.506^{* *} \\
(0.254)\end{array}$ \\
\hline Endogenous Elec & & & & & & & $\begin{array}{c}0.533 \\
(0.502)\end{array}$ & $\begin{array}{c}0.529 \\
(0.500)\end{array}$ & $\begin{array}{c}0.529 \\
(0.500)\end{array}$ \\
\hline Elec & $\begin{array}{c}0.534 * * \\
(0.228) \\
\end{array}$ & $\begin{array}{c}0.516^{* *} \\
(0.230)\end{array}$ & $\begin{array}{l}0.516^{* *} \\
(0.230)\end{array}$ & $\begin{array}{c}0.600^{* *} \\
(0.252)\end{array}$ & $\begin{array}{c}0.575^{* *} \\
(0.251)\end{array}$ & $\begin{array}{l}0.574 * * \\
(0.250)\end{array}$ & & & \\
\hline Observations & 1079 & 1079 & 1079 & 702 & 702 & 702 & 1079 & 1079 & 1079 \\
\hline Countries & 66 & 66 & 66 & 50 & 50 & 50 & 66 & 66 & 66 \\
\hline $\mathrm{p}$ value $\mathrm{F}$ first Stage (fiscal rules) ${ }^{c}$ & & 0.000 & 0.000 & & 0.000 & 0.000 & & 0.000 & 0.000 \\
\hline $\mathrm{p}$ value $\mathrm{F}$ first stage (Interaction) ${ }^{c}$ & & 0.000 & 0.000 & & 0.000 & 0.000 & & 0.000 & 0.000 \\
\hline $\mathrm{p}$ value $\mathrm{SW}$ chi2 & & 0.000 & 0.000 & & 0.000 & 0.000 & & 0.000 & 0.000 \\
\hline $\mathrm{p}$ value $\mathrm{SW}$ chi2 (interaction) & & 0.000 & 0.000 & & 0.000 & 0.000 & & 0.000 & 0.000 \\
\hline p value Hansen j Statistic & & 0.401 & 0.401 & & 0.341 & 0.341 & & 0.429 & 0.429 \\
\hline
\end{tabular}

Notes: All Specifications include country-specific linear trends and the set of control variables. The within estimator is used to eliminate the country fixed effects. FR index is Fiscal rules index (all types). Columns (1)-(3) show estimates for all elections and Pred = "Predetermined election dates". Columns (4)-(6) show estimates on the subsample of democratic countries and Columns (7)-(9) take into account the endogeneity of the electoral calendar. c: p value F test (weak identification) Sanderson and Windmeijer (2015) for excluded instruments. p value SW chi2 is the p value of Sanderson and Windmeijer (2015) test for underidentification (H0: the endogenous variable is unidentified). LIML is the Limited Maximum Likelihood estimator. * $p<0.10, * * p<0.05, * * * p<0.01$. 


\section{Appendix}

\section{Appendix A: Countries in the sample}

Argentina, Bangladesh , Barbados, Belize, Bolivia, Botswana, Brazil, Burkina Faso, Burundi, Cameroon, Central African Republic, Chad, Colombia, Congo Dem. Rep., Costa Rica, Cote d'Ivoire, Dominican Republic, Ecuador, Egypt, El Salvador, Ethiopia, Fiji, Gabon, Gambia, Ghana, Guinea-Bissau, Honduras, India, Indonesia, Iran, Islamic Rep., Jamaica, Jordan, Kenya, Lesotho, Liberia, Madagascar, Malawi, Malaysia, Mali, Mauritius, Mexico, Morocco, Mozambique, Nepal, Nicaragua, Niger, Pakistan, Panama, Papua New Guinea, Paraguay, Peru, Philippines, Rwanda, Senegal, Sri Lanka, Suriname, Syrian Arab Republic, Tanzania, Thailand, Togo, Tunisia, Turkey, Uganda, Uruguay, Venezuela, Zambia, Zimbabwe.

Appendix B

Summary statistics

\begin{tabular}{lccccc}
\hline \multicolumn{1}{c}{ Variable } & Obs & Mean & Std. Dev. & Min & Max \\
\hline General government consumption in \% of GDP (WDI) & 1190 & 13.867 & 5.361 & 2.976 & 41.659 \\
Elec (NELDA) & 1190 & 0.102 & 0.247 & 0 & 0.997 \\
FR (IMF Fiscal rules dataset, 2012) & 1190 & 0.074 & 0.262 & 0 & 1 \\
FR index (IMF Fiscal rules dataset, 2012) & 1080 & 0.151 & 0.616 & 0 & 4.055 \\
Growth (WDI) & 1190 & 1.596 & 4.52 & -32.235 & 16.236 \\
Log Openness in \% of GDP (WDI) & 1190 & 4.087 & 0.535 & 2.382 & 5.395 \\
Log (100+Inflation) & 1190 & 4.784 & 0.414 & 4.481 & 10.107 \\
Aid per capita (Log) (WDI) & 1190 & 3.016 & 1.301 & -2.381 & 5.58 \\
Government fragmentation (DPI) & 1190 & 0.172 & 0.262 & 0 & 0.893 \\
Right wing (DPI) & 1190 & 0.23 & 0.421 & 0 & 1 \\
Public debt in \% of GDP (Log) $(t-1)$ (Abbas et al., 2010) & 1190 & 4.159 & 0.585 & 1.717 & 6.26 \\
GDP per capita (Log) (WDI) & 1190 & 6.916 & 1.138 & 4.567 & 9.189 \\
Polity2 ( Polity IV Database, Marshall \& Jaggers, 2005) & 1136 & 2.347 & 6.265 & -9 & 10 \\
Neighbors & 1190 & 1.019 & 1.615 & 0 & 6 \\
\hline
\end{tabular}




\section{Appendix C}

Year of adoptions and features of the rules

\begin{tabular}{|c|c|c|c|c|c|c|}
\hline Country & ER & BBR & DR & RR & Monitoring & Coverage \\
\hline Argentina & 2000 & 2000 & & & BBR (Yes) ER (No) & GG \\
\hline Botswana & 2003 & 2005 & 2005 & & No & CG \\
\hline Brazil & 2000 & & 2000 & & Yes & GG \\
\hline Costa Rica & & 2001 & & & Yes & CG \\
\hline Ecuador & & 2003 & 2003 & & Yes & BBR (CG) DR (GG) \\
\hline India & & 2004 & & & No & CG \\
\hline Indonesia & & 1967 & 2004 & & No & GG \\
\hline Kenya & & & 1997 & 1997 & No & CG \\
\hline Mexico & & 2006 & & & Yes & CG \\
\hline Pakistan & & 2005 & 2005 & & No & CG \\
\hline Panama & & $2002-2003$ & $2002-2003$ & & No & GG \\
\hline Peru & 2000 & 2000 & & & BBR(Yes) ER(No) & CG \\
\hline Sri Lanka & & 2003 & 2003 & & No & CG \\
\hline
\end{tabular}

$\mathrm{BBR}=$ Balanced Budget Rule, $\mathrm{DR}=$ Debt Rule, $\mathrm{ER}=$ Expenditure Rule, $\mathrm{RR}=$ Revenue Rule, $\mathrm{CG}=$ Central government, $\mathrm{GG}=\mathrm{General}$ Governent. Monitoring (Monitoring of Compliance outside the government). Panama's rules were in place for only 2 years.

Source: Schaechter et al. (2012)

Appendix D

Evidence of political budget cycle in the sample

\begin{tabular}{lcccccc}
\hline & $(1)$ & $(2)$ & $(3)$ & $(4)$ & $(5)$ & $(6)$ \\
\hline Elec & & & & & & \\
& $0.485^{* *}$ & $0.483^{* *}$ & $0.663^{* * *}$ & $0.657^{* * *}$ & & \\
FR & $(0.201)$ & $(0.200)$ & $(0.217)$ & $(0.215)$ & & \\
& & -0.362 & & -0.531 & & -0.356 \\
Predet Elec & & $(0.761)$ & & $(0.915)$ & & $(0.758)$ \\
& & & & & $0.404^{*}$ & $0.404 *$ \\
Endogenous Elec & & & & & $(0.229)$ & $(0.229)$ \\
& & & & & 0.792 & 0.783 \\
Observations & 1190 & 1190 & 768 & 768 & 1190 & 1190 \\
Countries & 67 & 67 & 51 & 51 & 67 & 67 \\
\hline
\end{tabular}

Notes: All Specifications include country-specific linear trends and the set of control variables. The within estimator is used to eliminate the country fixed effects. FR= Fiscal rules dummy (all types). Columns (1)-(2) show estimates for all elections and Pred Elec = "Predetermined election dates". Columns (3)-(4) show estimates on the subsample of democratic countries and Columns (5)-(6) take into account the endogeneity of the electoral calendar. * $p<0.10, * * p<0.05, * * * p<0.01$. 
Appendix E

Baseline result - Controlling for sub-regional common shocks

\begin{tabular}{|c|c|c|c|c|c|c|}
\hline & $\begin{array}{c}(1) \\
\text { Base (OLS) }\end{array}$ & $\begin{array}{c}(2) \\
\text { Base (IV) }\end{array}$ & $\begin{array}{c}(3) \\
\text { Dem (OLS) }\end{array}$ & $\begin{array}{c}(4) \\
\text { Dem (IV) }\end{array}$ & $\begin{array}{c}(5) \\
\text { Pred (OLS) }\end{array}$ & $\begin{array}{c}(6) \\
\text { Pred (IV) }\end{array}$ \\
\hline Elec $\times$ FR & $\begin{array}{c}-1.028^{* * *} \\
(0.341)\end{array}$ & $\begin{array}{c}-3.104^{* *} \\
(1.318)\end{array}$ & $\begin{array}{c}-\mathbf{1 . 0 4 4}^{* * *} \\
(0.316)\end{array}$ & $\begin{array}{c}-3.675^{* *} \\
(1.624)\end{array}$ & & \\
\hline Predet Elec $\times$ FR & & & & & $\begin{array}{c}-0.756^{* * *} \\
(0.241)\end{array}$ & $\begin{array}{c}-2.362^{* *} \\
(1.136)\end{array}$ \\
\hline FR & $\begin{array}{l}-0.256 \\
(0.762)\end{array}$ & $\begin{array}{c}2.225 \\
(3.213)\end{array}$ & $\begin{array}{l}-0.403 \\
(0.897)\end{array}$ & $\begin{array}{c}1.265 \\
(2.846)\end{array}$ & $\begin{array}{l}-0.248 \\
(0.767)\end{array}$ & $\begin{array}{c}1.383 \\
(2.965)\end{array}$ \\
\hline Predet Elec & & & & & $\begin{array}{l}0.509^{* *} \\
(0.245)\end{array}$ & $\begin{array}{l}0.681^{* *} \\
(0.313)\end{array}$ \\
\hline Endogenous Elec & & & & & $\begin{array}{l}0.833^{*} \\
(0.487)\end{array}$ & $\begin{array}{l}0.955^{*} \\
(0.494)\end{array}$ \\
\hline Elec & $\begin{array}{c}0.592^{* * *} \\
(0.213)\end{array}$ & $\begin{array}{c}0.803^{* * *} \\
(0.278)\end{array}$ & $\begin{array}{c}0.769^{* * *} \\
(0.232)\end{array}$ & $\begin{array}{c}1.066^{* * *} \\
(0.313)\end{array}$ & & \\
\hline sub-regional economic growth & Yes & Yes & Yes & Yes & Yes & Yes \\
\hline global economic growth & Yes & Yes & Yes & Yes & Yes & Yes \\
\hline Observations & 1181 & 1181 & 768 & 768 & 1138 & 1138 \\
\hline Countries & 66 & 66 & 51 & 51 & 63 & 63 \\
\hline $\mathrm{p}$ value $\mathrm{F}$ first Stage $\left(\right.$ fiscal rules) ${ }^{c}$ & & 0.018 & & 0.030 & & 0.018 \\
\hline $\mathrm{p}$ value $\mathrm{F}$ first stage (Interaction) ${ }^{c}$ & & 0.017 & & 0.027 & & 0.018 \\
\hline
\end{tabular}

Notes: All Specifications include country-specific linear trends and the set of control variables. The within estimator is used to eliminate the country fixed effects. Global economic growth and sub-regional economic growth are taken from the WDI. FR= Fiscal rules dummy (all types). Columns (1)-(2) show estimates for all elections and Pred = "Predetermined election dates". Columns (3)-(4) show estimates on the subsample of democratic countries and Columns (5)-(6) take into account the endogeneity of the electoral calendar. c: F test Angrist and Pischke (2009) for excluded instruments with H0: "weak identification". * $p<0.10, * * p<0.05, * * * p<0.01$. 